\title{
An Examination of the Determinants of the Adoption of Mobile Applications as Learning Tools for Higher Education Students
}

\author{
https://doi.org/10.3991/ijim.v13i03.10195 \\ Tinashe Chuchu $\left({ }^{\varpi}\right)$, Tinashe Ndoro \\ University of Pretoria, Pretoria, South Africa \\ tinashe.chuchu@up.ac.za
}

\begin{abstract}
The main purpose of the present study was to examine whether mobile applications could be adopted as feasible tools for learning purposes at higher education institutions. Furthermore the study's intention was to conduct an empirical investigation into students' perceptions towards mobile applications being introduced as learning aids. The researcher developed a conceptual model derived from the technology acceptance model in order to measure the constructs used in the study. Adopting a quantitative approach, the field study was conducted in South Africa at a selected higher education institution. Research data was collected from 380 registered students at the selected higher education institution who were older than 18 years. Using SPSS 23 and AMOS 23 software programs, Structural Equation Modeling (SEM) was performed to analyse the data set. The results revealed that perceived usefulness, perceived ease of use, attitudes towards a mobile application, intention to use a mobile application were all significant predictors for the actual use of mobile applications for learning. The findings of the study illuminate the importance of the determinants of the adoption of mobile applications for learning in higher education.
\end{abstract}

Keywords - Technology, mobile application, students, higher education

\section{Introduction}

The advent of mobile education technologies into teaching and learning has given rise to both new opportunities and challenges to educators (Handal, El-Khoury, Campbell \& Cavanagh, 2013) [21].The rapid advance in broadband and wireless internet technologies has promoted the utilisation of wireless applications in our daily lives (Hwang, Yang, Tsai \&Yang, 2009). Application software, also referred to as an application or an app, relates to a software designed to assist users in performing specific or various related tasks (Handal, El-Khoury, Campbell and Cavanagh, 2013) [21]. Advancement in mobile technology and learning applications have broadened the scope of learning areas outside of formal education by allowing flexible and instant access to rich digital learning sources (Cheon, Lee, Crooks \& Song, 2012) [13]. Access to mobile online lectures can provide an opportunity for learning by students while commuting (Massey, Ramesh \& Khatri, 2006) [37]. For example eSchoolBag, is a platform that 
allows students to download/upload homework, access class announcements and complete exercises, anywhere, anytime (Massey et al., 2006) [37].

Education in particular has benefitted from technologies such as computers and the internet (Abdullah, Ward \& Ahmed, 2016) [1]. Being economical, flexible and accessible without constraints of time and distance, technologies such as electronic learning (e-learning) systems are becoming increasingly relevant in the Higher Education context (Abdullah et al., 2016 [1]; Lin, Lu \& Liu, 2013) [35]. An e-learning system is defined by Lee, Hsieh and Ma (2011) [32] as an information system that can integrate a wide variety of instructional elements through audio, video, and text delivered through live chat sessions, online discussions, forums, tests and assignments. The present study will primarily focus on the adoption of mobile applications as educational tools. The study used the Technology Acceptance Model (Davis, Bagozzi \& Warshaw, 1989) [18] to examine the determinants of the adoption of educational mobile applications in higher education.

In numerous empirical studies (Ong \& Lai, 2006 [42]; Pituch \& Lee, 2006 [45]; Sánchez \& Hueros, 2010) the utility and applicability of the Technology Acceptance Model (TAM) has been supported in a wide range of educational settings. Wang, Wiesemes and Gibbons (2012) [56] define mobile applications for educational purposes as learning tools used to gain knowledge through mobile devices. Mobile devices include mobile devices such as tablets and smartphones. Nonetheless, mobile devices facilitate mobile learning (m-learning) which involves a form of learning that makes use of mobile communication technologies that give students the capacity to continuously learn anywhere and anytime (Moreira, Santos \& Durao, 2017) [41]. According to Rainie (2012) [46] over $60 \%$ of young adults aged between 18-29 years, own smartphones and use them for a variety of purposes such as, surfing the internet for information, texting, social networking and reading emails. This therefore reveals how significant a role smartphones play in young adult's lives. Smartphones and mobile apps have developed into an everyday staple in the lives of young people including Higher education students (Green, Cantu \& Wardle, 2014 [20]; Moreira et al., 2017) [46].

\subsection{Problem investigated}

The South African higher education landscape is faced by a plethora of challenges which include transformation, student unrests and poor student graduation rates (Barkhuizen, Rothmann \& Van de Vijver, 2013 [6]; Barkhuizen \& Rothmann, 2006 [5]; Letseka \& Maile, 2008 [34]). Mobile applications have the potential to positively support teaching and learning in higher education institutions by providing universal communication, study aids and flexible location-based services for learners (Cheon et al., 2012) [12]. Moreover, the higher education landscape is particularly suitable for the integration of student centred mobile educational applications to be adopted because mobile devices have become ubiquitous on university campuses among both students and staff members in both developed and developing countries (Cheon et al., 2012 [12]; Rogers, Palmer \& Miller, 2017). According to the International Telecommunication Union (ITU) (2015), seven billion people in the world have access to mobile devices 
coverage. Africa has the second largest and fastest growing mobile phone market in the world (ITU, 2015). According to Phuangthong and Malisawan (2005) [44], most researchers have focused on mobile applications, users' acceptance and the application of mobile learning in developed countries (Brown, Ryu \& Parsons, 2006 [7]; Liu, 2008 [36] and Chao and Chen (2009) [10]. However, limited research has explored the adoption of mobile devices to facilitate learning in higher education institutions within the African context (Kaliisa \& Picard, 2017) [26].

Open the document you would like to format and import the styles. How this works depends very much on the version of MS WORD that you use. The styles' names to be used for online-journals.org are preceded by a "0_" which makes them appear first in the styles list and therefore easier to be found.

Now just place the cursor in the paragraph you would like to format and click on the corresponding style in the styles window (or ribbon).

\section{$2 \quad$ Literature Review}

Baker (2000) [4] considers reviewing current literature relevant to a research interest to be an essential initial step and basis for undertaking the research study. In an educational environment, students can utilise mobile devices to support their learning. Mobile devices , such as personal digital assistants (PDAs), mobile phones, or portable computers are increasingly being incorporated in learning activities by educators $(\mathrm{Wu}$, Hwang, Tsai, Chen \& Huang, 2011) [57]. This research focuses on problem solving in education utilizing technology, which echoes past research from Sediyono, Kristinawati and Paseleng (2018) [49]. In this respect, mobile technology, allows learning activities to be carried out inside and outside of the classroom (Wu et al., 2011) [57]. Researchers have established that what really matters is students being able to access the right educational resources at the right time in the right place (Shih, Chu \& Hwang, 2011[51] and Wu et al., 2011) [57].

As a form of learning, mobile learning involves learning, which is facilitated by mobile devices. Mobile learning provides continuous opportunities to extend spaces and times for learning by learners (McCaffrey, 2011) [38].

There are four types of learning approaches that can be supported by mobile devices, namely:

- Individualized learning

- Situated learning

- Collaborative learning

- Informal learning

Through individualized learning, mobile learning allows students to pace themselves as they learn and acquire knowledge. On the other hand, situated learning occurs when students utilize mobile devices to learn within a real life context. Collaborative learning occurs when students utilize mobile devices to interact and share knowledge with other students. Finally, informal learning occurs when students are able to utilize their mobile devices out of the classroom setting at their convenience (Wu et al., 2011) [57]. Several 
studies focusing on the use of mobile devices to facilitate learning have provided empirical evidence supporting the effectiveness of mobile devices in the learning process. For example, in a study conducted by Hwang, Yang, Tsai and Yang (2009) [24] mobile and wireless communication technologies were used in a Chemistry course to train students on the operating procedure of the single-crystal X-ray diffraction experiment. In this vein, mobile applications have been reported to facilitate learning activities, which include, sharing of information, robust debates and the discussions of important topics.

The potential benefits of mobile applications as learning tools has received extensive support in terms of being cost saving, ubiquitous, and convenient (Cheon et al., 2012) [12]. According to Young (2011), mobile applications on mobile devices can be used as study aids that can be easily accessed by learners when they are at home during any time of the day.

The characteristics of mobile devices are three fold:

- Portability - mobile device can be taken to any location because of their size

- Instant connectivity - because of the wide spread accessibility of the internet mobile devices can be used to access any information instantly

- Context sensitivity - with regard to the availability of the internet, any use of mobile devices can be tracked and measured to gather necessary data and information (Churchill \& Churchill, 2008 [14]; Klopfer, Squire \& Jenkins, 2002 [28]; Sharples, 2000 [50]).

Recent research showed that $67 \%$ of students' smartphones and tablets are reportedly being used for academic purposes (Chen \& Denoyelles, 2013) [11]. Research also indicates that most students use mobile devices for academic applications including university applications (such as, UCF mobile, Tegrity, Mobile learn), educational application (such as, Flash cards, Khan Academy and iTunes U), e-books (such as, Course Smart and Inkling), Google and Safari for accessing information (Chen et al, 2012) [11].

The following sections in the paper will comprise of the theoretical grounding underpinning the study, research objectives, hypotheses, research methodology, findings/results, managerial and academic implications, conclusions and lastly suggestions for future research.

\subsection{Theoretical grounding}

For the purpose of this study the theoretical grounding will be guided by, the Technology Acceptance Model (Davis et al., 1989) [18], Theory of Planned Behaviour (Ajzen, 1991) and the Theory of Reasoned Action (Ajzen \& Fishbein, 1975). These theories were be used to explain students' behaviour towards the adoption of mobile applications as learning tools. Moreover, this study will add to our understanding of theory through the application of the aforementioned theories within the African higher education context to comprehend the adoption of mobile applications as learning tools.

Technology Acceptance Model: The technology acceptance model (TAM) proposed by Davis (1989) [17] is the most widely used and recognized theory for explaining an individual's acceptance and adoption of information technology (Lee, Hsieh \& 
Hsu, 2011) [32]. TAM determines user's attitudes and recognises the role of perceived ease of use (PEOU) and perceived usefulness (PU) in the comprehension of user's acceptance of information systems (Min, So \& Jeong, 2018 [39]; Taylor \& Todd, 1995 [53]; Venkatesh \& Davis, 2000) [55]. Increasingly, TAM has been used as an explanatory tool in investigating $\mathrm{m}$ learning amongst students. In a study conducted by Park, Nam and Cha (2012) [43] it was found that the TAM is an acceptable model to explain student's acceptance of $m$ learning. TAM highlights the importance of two key dimensions, namely, Perceived Usefulness (PU) and Perceived Ease of Use (PE). In this vein, PU represents the extent to which individuals believe that technology will aid them in achieving their intended outcomes. On the other hand, PE denotes the extent to which an individual believes that adopting technology will ease and support their cognitive efforts (Park et al., 2012) [43].

Theory of Reasoned Action: According to Tsai, Chen and Chien (2012) [53] the theory of reasoned action is widely used to explain human behaviour. According to theory of reasoned action (Ajzen \& Fishbein 1975) [3], intentions are the sole determinant of the behaviour (Sommer, 2011) [52]. According to the theory of reasoned action (Ajzen \& Fishbein, 1975) [3] in order for an individual to fully engage in a certain behaviour, their behaviour is driven by their intentions.

Theory of Planned Behaviour: The theory of planned behaviour (TPB) is a theory intended to predict and explain human behaviour in specific settings (Ajzen, 1991) [2] . The theory of planned behaviour is an extension of the theory of reasoned action, which addresses the limitation of the theory of reasoned action in not accounting for behaviours in which individuals do not have complete voluntary control. Hence, the theory of planned behaviour has the additional component of perceived behaviour control has a determinant for behaviour intention (Ajzen, 1991) [2].

\section{$3 \quad$ Research Objectives}

The main objective of the literature was to investigate the determinants of the adoption of mobile applications as learning tools by students in higher education.

\section{$4 \quad$ Research Conceptual Model}

In the conceptual model adapted from the TAM (Davis, Bagozzi \& Warshaw, 1989) [18], Theory of Planned Behaviour (Ajzen, 1991) [2] and the Theory of Reasoned Action (Ajzen \& Fishbein, 1975) [3], perceived usefulness, perceived ease of use, attitudes on mobile applications, intentions to use mobile applications and the actual use of mobile applications will be presented. Based on the conceptual model, hypotheses are developed for the present study. 


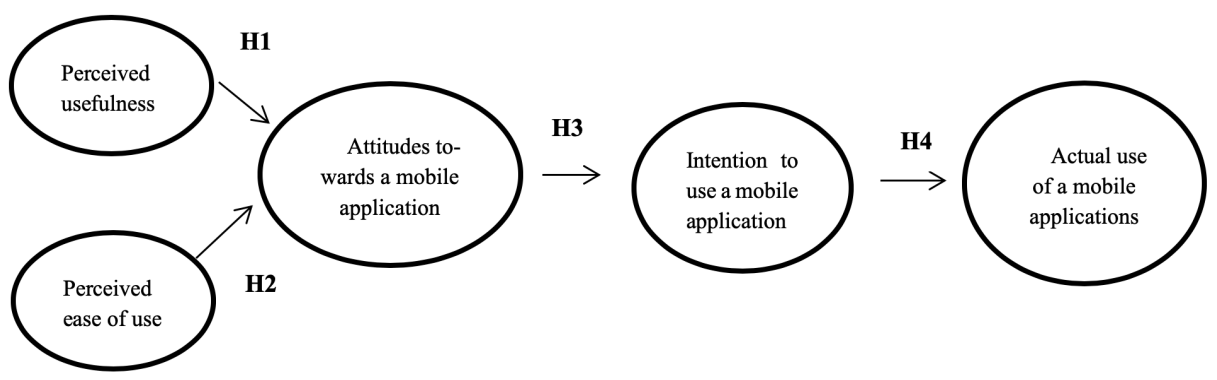

Fig. 1. The proposed conceptual model

\subsection{Hypotheses development}

Perceived usefulness and Attitudes towards a mobile application: According to literature, perceived usefulness is a construct used to measure user's satisfaction with information systems (Calisir \& Calisir, 2004) [15]. In empirical research, perceived usefulness has been identified as an important predictor for the adoption technology systems such as mobile payments, mobile commerce and mobile learning (Brown et al., 2006 [7]; Chao \& Chen, 2009) [10]. Furthermore, it is believed that if a particular technology system is useful in one's daily life and activities it will automatically change their attitudes towards it. Perceived usefulness is an important determinant for an individual's acceptance and usage of information technology, the features of the technology, and the targeted users acceptance of the technology. Within the educational context, perceived usefulness is noted to positively influence users' attitudes towards mobile application tools as learning and educational tools (Chen et al., 2012 [57]; Moon \& Kim, 2001) [40]. Kim and Woo (2016) [27] suggest that ease of use positively influences attitudes towards technology. Therefore, inferring from the literature and the abovementioned empirical evidence, the study hypothesises that

H1: There is a positive relationship between perceived usefulness and attitudes towards mobile applications among higher education students.

Perceived ease of use and attitudes towards mobile applications: Perceived ease of use refers to the degree to which a particular user of a technology system views it as easy and with less effort to use (Chang, Kim and Oh, 2002; Koo, 2003; Chang, Yan and Tseng, 2012). Lee, Cheung and Chen (2005) [31] suggest that perceived ease of use can be seen as a moderate predictor of the intention to use technological devices as educational tools. However, Kim and Woo (2016) [27] argue that ease of use positively and strongly influences attitudes towards technology. Within the educational context, perceived ease of is noted as an important determinant for an individual to accept and adopt on information technology to aid in their learning (Moon et al, 2001) [40]. Therefore, inferring from the literature and the empirical evidence abovementioned, the study hypothesizes that:

H2: There is a positive relationship between perceived ease of use and attitudes toward mobile applications among higher education students.

Attitudes towards a mobile application and intention to use mobile applications: An attitude towards a behaviour relates to an individual's positive or negative 
feelings towards performing the behaviour (Cheon et al., 2012) [12]. Attitudes towards using technology positively and directly influences the behavioural intention to use that technology (Kim \& Woo, 2016) [27]. Attitudes towards using and accepting technology are included as a key construct in TAM (Chang et al., 2012). Therefore, deducing from the literature and the abovementioned empirical evidence, the study hypothesizes that:

H3: There is a positive relationship between attitudes towards a mobile application and the intention to use that mobile application among higher education students.

Intentions to use a mobile application and actual use of the mobile application

Intention refers to an individual's motivation in his or her's conscious plan to exert effort to carry out behaviour (Eagly \& Chaiken, 1993) [19]. According to Venkatesh and Davis (2000) [55] intentions to use a certain type of technology system have a direct influence on the actual use of that technology system. Research by several scholars (such as, Hong, Thong Moon \& Tam, 2008 [22]; Moon \& Kim, 2001 [40]; Hong, Thong \& Tam, 2006) [23] on students and mobile applications has shown that students' behaviour towards adopting mobile learning tools is guided by reasoned conscious intentions towards the use of these mobile applications as learning tools. Drawing from TAM, Lee et al., (2013) [30] purport that a user's intention to adopt mobile applications is the most immediate predictor of the actual usage of the mobile applications. Therefore, inferring from the literature and the abovementioned empirical evidence, the study hypothesizes that:

H4: There is a positive relationship between the intention to use a mobile application and the actual use of that mobile application among higher education students.

\section{$5 \quad$ Research Methodology}

\subsection{Research design}

The study utilised the positivist paradigm, a philosophy that is of the view that knowledge stems from human experience (Collins, 2010) [16]. A quantitative research approach was adopted for this study whereby a 28 -item survey questionnaire was selfadministered to 380 research participants at a selected South African university. Convenience sampling was adopted to select the research participants (students), which involves selecting suitable participants who are willing to participate in the study (Collins, 2010) [16]. In the present study, due to the difficulty in obtaining suitable and willing research participants within the research setting, convenience sampling was deemed suitable as recommended by (Collins, 2010) [16]. Furthermore, drawing from the methodological precepts adopted by Cheon et al., (2012) [12], data analysis through Structural Equation Modeling (SEM) was deemed suitable for the sample obtained through the convenience sampling process in the study. The data for the research in question was normally distributed therefore qualifying it for a SEM analysis as indicated in table 4 with standard deviation values ranging from 0,896 to 1,045 falling within the recommended threshold of -2 and +2 . 


\subsection{Measurement instrument}

The research constructs in the research instrument were developed and adapted from previous studies investigating similar phenomenon. The research instrument consisted of two sections namely; Demographic section and 5 point Likert scale type questions based on the research conceptual model. The Likert scale was measured from $1=$ Strongly disagree; $3=$ Neutral; $5=$ Strong agree. In terms of data analysis SPSS 23 and AMOS 23, software programs were used to perform SEM.

\section{Results / Findings}

Table 1. Sample Demographic Profile

\begin{tabular}{|l|c|c|c|c|c|}
\hline \multicolumn{1}{|c|}{ Gender } & Frequency & Percentage & Age & Frequency & Percentage \\
\hline Female & 166 & 43.7 & $18-19$ & 232 & 61.1 \\
\hline Male & 214 & 56.3 & $20-25$ & 133 & 35 \\
\hline Total & 380 & 100 & $26+$ & 15 & 3.93 \\
\hline & & & Total & 380 & 100 \\
\hline & & & & & \\
\hline Marital Status & Frequency & Percentage & Academic level & Frequency & Percentage \\
\hline Single & 13 & 96.6 & High School & 317 & 83.4 \\
\hline Married & 367 & 3.4 & Diploma & 6 & 1.6 \\
\hline Total & 380 & 100 & Degree & 43 & 1.3 \\
\hline & & & Post-graduate & 13 & 3.4 \\
\hline & & & Other & 1 & 0.3 \\
\hline & & & Total & 380 & 100 \\
\hline
\end{tabular}

As indicated in table 1 above, female participants represented $43.7 \%$ of the total sample whereas male participants accounted for $56.3 \%$ of the total sample. In terms of the participants educational levels most of the participants had a high school qualification as indicated by 317 out of a total of 380 participants. Participants with a post-graduate qualification had the least representation as indicated by only 13 out of the total 380. The following section illustrates the inter-construct correction matrix of the study's constructs.

Table 2. Correlations between Constructs

\begin{tabular}{|l|c|c|c|c|c|}
\hline \multicolumn{7}{|c|}{ Inter-construct Correlations Matrix } & $\boldsymbol{P U}$ & $\boldsymbol{P E U}$ & $\boldsymbol{A T T}$ & $\boldsymbol{I}$ & $\boldsymbol{A U}$ \\
\hline & 1 & & & & \\
\hline Perceive Usefulness (PU) & $0.521^{* *}$ & 1 & & & \\
\hline Perceived Ease of Use (PEU) & $0.676^{* *}$ & $.527^{* *}$ & 1 & & \\
\hline Attitudes Toward Mobile Applications (ATT) & $0.599^{* *}$ & $.420^{* *}$ & $.721^{* *}$ & 1 & \\
\hline Intentions To Use Mobile Applications (I) & $0.464^{* *}$ & $0.389^{* *}$ & $0.554^{* *}$ & $.515^{* *}$ & 1 \\
\hline Actual Use of Mobile Applications (AU) & \\
\hline **Correlation is significant at the 0.01 level (2-tailed).
\end{tabular}

The inter-construct correlation matrix was used to test for discriminant validity of the research constructs. Correlations among latent constructs were evaluated in order 
to observe if they were, lower than 1.0. As indicated in table 2 below, the inter-correlation values for all paired latent variables are below 1, therefore, implying that there is the presence of discriminant validity (Chinomona, Lin, Wang \& Cheng, 2010) [13]. Below is table 3, which depicts the model, fit for the study's research data. It can be observed that all the model fit indices met the required thresholds.

Table 3. Model Fit

\begin{tabular}{|l|c|c|c|c|c|c|c|c|}
\hline Model fit criteria & $(\boldsymbol{\chi} \mathbf{2} / \mathbf{D F})$ & GFI & CFI & IFI & NFI & RFI & TLI & RMSEA \\
\hline Indicator value & 1,713 & 0,926 & 0,970 & 0,970 & 0,932 & 0,918 & 0,964 & 0,043 \\
\hline
\end{tabular}

( $\chi 2 / \mathrm{DF})$ : Chi-square, GFI: Goodness of fit index, CFI: Confirmatory fit index, IFI: Incremental fit index, NFI: Normed fit index, RFI: Relative fit index, TLI: Tucker Lewis index, RMSEA: Root mean standard error approximation

\subsection{Scale accuracy analysis}

Results of scale reliability are presented in table 4 whereby Cronbach's alpha coefficients were above 0.8 while the composite reliability values ranged from 0.824 to 0.882 . Furthermore, it was observed that most of the AVE values ranged from 0.644 to 0.750 . The measurement model produced a ratio of chi-squared value over degree-offreedom of 1.713, which is acceptable as it falls below the recommended 3 recommended (Ullman, 2001). Other model fit indices that included the GFI, CFI, IFI, NFI, RFI and TLI were $0.926,0.970,0.970,0.932,0.918$ and 0.964 respectively. All these model fit measures were above the recommended threshold of 0.8 (Chinomona, Lin, Wang, \& Cheng 2010) [13]. The RMSEA was 0.043, which fell below the recommended threshold of 0.08 .

Table 4. Accuracy Analysis Statistics

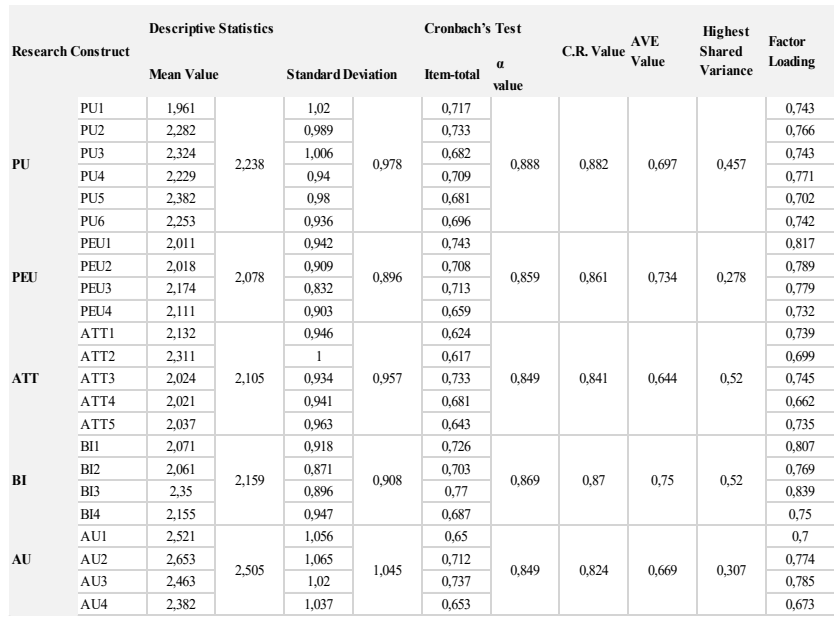

$\chi^{2} / \mathrm{df}=1.713, \mathrm{GFI}=0.926, \mathrm{CFI}=0.970, \mathrm{NFI}=0.932, \mathrm{RMSEA}=0.043 ;{ }^{\text {a }}$ significance level significance level significance level $\mathrm{p}<0.001$

* Scores: 1 - Strongly Agree; 3 - Neutral; 5 -Strongly Disagree. 


\subsection{Path modeling and hypotheses testing}

Table 5 presents the results of the structural equation modeling followed by a discussion

Table 5. Results of sructural equation model analysis

\begin{tabular}{|l|c|c|c|c|}
\hline \multicolumn{1}{|c|}{$\begin{array}{c}\text { Proposed Hypothesis } \\
\text { Relationship }\end{array}$} & Hypothesis & $\begin{array}{c}\text { Factor } \\
\text { Loading }\end{array}$ & P Value & Outcome \\
\hline $\begin{array}{l}\text { Perceived usefulness (PU) } \\
\text { Attitudes (ATT) }\end{array}$ & $\mathrm{H} 1$ & 0.64 & $* * *$ & Supported and significant \\
\hline $\begin{array}{l}\text { Perceived ease of use (PEU) } \\
\text { Attitudes (ATT) }\end{array}$ & $\mathrm{H} 2$ & 0.23 & $* * *$ & Supported and significant \\
\hline $\begin{array}{l}\text { Attitudes on mobile applications } \\
\begin{array}{l}\text { ATT) } \\
\text { Intention to use (I) }\end{array}\end{array} \quad \mathrm{H} 3$ & 0.88 & $* * *$ & Supported and significant \\
\hline $\begin{array}{l}\text { Intention to use (I) } \\
\text { Actual use (AU) }\end{array}$ & $\mathrm{H} 4$ & 0.68 & $* * *$ & Supported and significant \\
\hline
\end{tabular}

\subsection{Discussion of hypotheses results}

It can be observed in table 5 that all four hypotheses are supported.

- From the first hypothesis (H1) it can be noted that perceived usefulness positively and significantly affects attitudes as indicated by a factor loading of 0.64. This implies that the more participants perceive mobile applications as useful products the more positive their attitudes become towards them.

- In terms of the second hypotheses (H2) which is supported by the findings, it can be observed that the perceived ease of use of mobile applications for educational purposes leads to the development of positive attitudes towards those applications.

- It can be seen that for the third hypothesis (H3), attitudes on mobile applications positively and significantly second hypotheses influence the intention to use those applications for educational purposes as indicated by a factor loading of 0.88 .

- Lastly for the forth hypothesis (H4) it can be noted that there is a positive relationship between the intention to use mobile applications and their actual use. This finding implies that the more the users' are motivated and intend to use mobile applications for educational purposes the more they will use and adopt the mobile applications.

\section{$7 \quad$ Managerial and Academic Implications}

The present study has both implications for academicians and managers in various ways. First, academicians would benefit significantly in understanding the acceptance and adoption of technology by students in their learning process. The study allows academics to gain insight of the interrelationships of the factors that influence the adoption of technology to facilitate learning by students. The study allows academics to ascertain the perceived usefulness of technology for learning by students within the South African context. The study can be used by Higher Education institutions within 
the South African context to facilitate learning through the use of technology platforms. From a marketing perspective, organizations that design online educational appliances can understand the factors that influence the adoption of online learning resources with Higher education institutions. Moreover, the findings of the study can aid organizations that develop online educational appliances to ascertain if their products would be viable in the market and the potential challenges they would face in launching those products.

\section{Conclusion}

The present study sort to investigate the determinants of the adoption of mobile applications by students at a selected Higher education institution. For purposes of the study, the Technology Adoption Model (TAM) adopted and adapted by the researchers. From the findings of the study it was found that student's attitudes towards the use of a mobile application was positively influenced by their perceived usefulness and perceived ease of use of the mobile applications. Attitudes positively influenced the student's intention to use the mobile applications. This research revealed that the use of a leaning application was well received by students reflecting the findings of (Zidoun, Talea, \& Dehbi, 2016) [58]. Additionally, Yunita, Nursechafia, Setiawan, Nugroho and Ramadhan (2018) established that mobile phone usage in classrooms was significantly beneficial to students, further supporting findings of the present study in question. Finally, student's actual adoption of mobile applications for learning purposes were directly influenced by their intention to use the mobile applications.

\section{$9 \quad$ Suggestions for Future Research}

Future research could be comparison in nature and include using students from more higher education institutions in South Africa to ascertain if there is a difference in the adoption of mobile applications by students from different Higher education institutions. Moreover, future research can involve the adoption of a qualitative research design in which participant's would be interviewed to gain a deep understanding of their technology adoption behaviour. A longitudinal study could be adopted to ascertain the changes in the adoption behaviour of students of technology. More research participants including academic staff members can be included in future research.

\section{References}

[1] Abdullah, F., Ward, R., \& Ahmed, E. (2016). Investigating the influence of the most commonly used external variables of TAM on students' Perceived Ease of Use (PEOU) and Perceived Usefulness (PU) of e-portfolios. Computers in Human Behavior, 63: 75-90. https://doi.org/10.1016/j.chb.2016.05.014

[2] Ajzen, I. (1991). The theory of planned behavior. Organizational behavior and human decision processes, 50(2): 179-211. https://doi.org/10.1016/0749-5978(91)90020-T 
[3] Ajzen, I., \& Fishbein, M. (1975). Belief, attitude, intention and behavior: An introduction to theory and research. Boston: Addison-Wesley.

[4] Baker, M. J. (2000). Writing a literature review. The Marketing Review, 1(2), 219-247. https://doi.org/10.1362/1469347002529189

[5] Barkhuizen, N., \& Rothmann, S. (2006). Work engagement of academic staff in South African higher education institutions. Management Dynamics: Journal of the Southern African Institute for Management Scientists, 15(1): 38-46.

[6] Barkhuizen, N., Rothmann, S., \& Van De Vijver, F. J. (2014). Burnout and work engagement of academics in higher education institutions: Effects of dispositional optimism. Stress and Health, 30(4): 322-332. https://doi.org/10.1002/smi.2520

[7] Brown, R., Ryu, H., \& Parsons, D. (2006, November). Mobile helper for university students: a design for a mobile learning environment. In Proceedings of the 18th Australia conference on Computer-Human Interaction: Design: Activities, Artefacts and Environments (pp. 297300). ACM.

[8] Chang, C. C., Yan, C. F., \& Tseng, J. S. (2012). Perceived convenience in an extended technology acceptance model: Mobile technology and English learning for college students. Australasian Journal of Educational Technology, 28(5): 809-826. https://doi.org/10 .14742 ajet. 818

[9] Chang, H. S., Kim, J. K., \& Oh, C. G. (2002). Technology acceptance model with web interactivity. The Journal of MIS research, 12(4): 55-75.

[10] Chao, P. Y., \& Chen, G. D. (2009). Augmenting paper-based learning with mobile phones. Interacting with Computers, 21(3): 173-185. https://doi.org/10.1016/j.intcom.2009.01.001

[11] Chen, B., \& Denoyelles, A. (2013). Exploring students' mobile learning practices in higher education. Educause Review. Retrieved from http://www. educause. Edu/ero/article/exploring-students-mobile-learning-practices-higher-education.

[12] Cheon, J., Lee, S., Crooks, S. M., \& Song, J. (2012). An investigation of mobile learning readiness in higher education based on the theory of planned behavior. Computers \& Education, 59(3): 1054-1064. https://doi.org/10.1016/j.compedu.2012.04.015

[13] Chinomona, R., Lin, J. Y. C., Wang, M. C. H., \& Cheng, J. M. S. (2010). Soft power and desirable relationship outcomes: the case of Zimbabwean distribution channels. Journal of African Business, 11(2): 182-200. https://doi.org/10.1080/15228916.2010.508997

[14] Churchill, D., \& Churchill, N. (2008). Educational affordances of PDAs: A study of a teacher's exploration of this technology. Computers \& Education, 50(4), 1439-1450. https://doi.org/10.1016/j.compedu.2007.01.002

[15] Calisir, F., \& Calisir, F. (2004). The relation of interface usability characteristics, perceived usefulness, and perceived ease of use to end-user satisfaction with enterprise resource planning (ERP) systems. Computers in human behavior, 20(4): 505-515. https://doi.org/10 $.1016 /$ i.chb.2003.10.004

[16] Collins, H. (2010). Creative research: the theory and practice of research for the creative industries. Ava Publishing.

[17] Davis, F. D. (1989). Perceived usefulness, perceived ease of use, and user acceptance of information technology. MIS Quarterly, 13(3): 319-340. https://doi.org/10.2307/249008

[18] Davis, F. D., Bagozzi, R. P., \& Warshaw, P. R. (1989). User acceptance of computer technology: a comparison of two theoretical models. Management science, 35(8), 982-1003. https://doi.org/10.1287/mnsc.35.8.982

[19] Eagly, A. H., \& Chaiken, S. (1993). The psychology of attitudes. Harcourt Brace Jovanovich College Publishers.

[20] Green, M., Cantu, A., \& Wardle, A. (2014, October). A study examining student preferences of mobile applications at an institution of higher learning in South Texas. In E-Learn: World 
Conference on E-Learning in Corporate, Government, Healthcare, and Higher Education (pp. 717-723). Association for the Advancement of Computing in Education (AACE).

[21] Handal, B., El-Khoury, J., Campbell, C., \& Cavanagh, M. (2013, September). A framework for categorising mobile applications in mathematics education. In Proceedings of The Australian Conference on Science and Mathematics Education (formerly UniServe Science Conference).

[22] Hong, S. J., Thong, J. Y., Moon, J. Y., \& Tam, K. Y. (2008). Understanding the behavior of mobile data services consumers. Information Systems Frontiers, 10(4): 431-445. https://doi.org/10.1007/s10796-008-9096-1

[23] Hong, S., Thong, J. Y., \& Tam, K. Y. (2006). Understanding continued information technology usage behavior: A comparison of three models in the context of mobile internet. Decision support systems, 42(3): 1819-1834. https://doi.org/10.1016/j.dss.2006.03.009

[24] Hwang, G. J., Yang, T. C., Tsai, C. C., \& Yang, S. J. (2009). A context-aware ubiquitous learning environment for conducting complex science experiments. Computers \& Education, 53(2): 402-413. https://doi.org/10.1016/j.compedu.2009.02.016

[25] Jiang, J. J., Hsu, M. K., Klein, G., \& Lin, B. (2000). E-commerce user behavior model: an empirical study. Human Systems Management, 19(4): 265-276.

[26] Kaliisa, R., \& Picard, M. (2017). A Systematic Review on Mobile Learning in Higher Education: The African Perspective. The Turkish Online Journal of Educational Technology, 16(1): 1-18.

[27] Kim, Y. G., \& Woo, E. (2016). Consumer acceptance of a quick response (QR) code for the food traceability system: Application of an extended technology acceptance model (TAM). Food Research International, 85: 266-272. https://doi.org/10.1016/j.foodres.2016.05.002

[28] Klopfer, E., Squire, K., \& Jenkins, H. (2002). Environmental detectives: PDAs as a window into a virtual simulated world. In Wireless and Mobile Technologies in Education, 2002. Proceedings. IEEE International Workshop on (pp. 95-98). IEEE. https://doi.org/10.1 109/WMTE.2002.1039227

[29] Koo, D. M. (2003). An investigation on consumer's internet shopping behavior explained by the technology acceptance model. Journal of Korean Management Information System, 14(1): 141-170.

[30] Lee, D. Y., \& Lehto, M. R. (2013). User acceptance of YouTube for procedural learning: An extension of the Technology Acceptance Model. Computers \& Education, 61: 193-208. https://doi.org/10.1016/i.compedu.2012.10.001

[31] Lee, M. K., Cheung, C. M., \& Chen, Z. (2005). Acceptance of Internet-based learning medium: the role of extrinsic and intrinsic motivation. Information \& management, 42(8): 1095-1104 https://doi.org/10.1016/j.im.2003.10.007

[32] Lee, Y. H., Hsieh, Y. C., \& Hsu, C. N. (2011). Adding innovation diffusion theory to the technology acceptance model: Supporting employees' intentions to use e-learning systems. Journal of Educational Technology \& Society, 14(4):124-137

[33] Lee, Y. H., Hsieh, Y. C., \& Ma, C. Y. (2011). A model of organizational employees'elearning systems acceptance. Knowledge-based systems, 24(3): 355-366. https://doi.org/10 .1016/j.knosys.2010.09.005

[34] Letseka, M., \& Maile, S. (2008). High university dropout radropouthreat to South Africa's future. Pretoria: Human Sciences Research Council.

[35] Lin, P. C., Lu, H. K., \& Liu, S. C. (2013). Towards An Education Behavioral Intention Model For E-Learning Systems: An Extension Of UTAUT. Journal of Theoretical \& Applied Information Technology, 47(3):1120-1127

[36] Liu, Y. (2008, July). An adoption model for mobile learning. In Paper presented at the IADIS e-commerce 2008 conference, Amsterdam, The Netherlands. 
[37] Massey, A. P., Ramesh, V., \& Khatri, V. (2006). Design, development, and assessment of mobile applications: the case for problem-based learning. IEEE Transactions on Education, 49(2): 183-192. https://doi.org/10.1109/TE.2006.875700

[38] McCaffrey, M. (2011). Why mobile is a must. Teaching in Higher Education Journal, 38(2): 21-22.

[39] Min, S., So, K. K. F., \& Jeong, M. (2018). Consumer adoption of the Uber mobile application: Insights from diffusion of innovation theory and technology acceptance model. Journal of Travel \& Tourism Marketing, 1-14. https://doi.org/10.1080/10548408.2018.1507866

[40] Moon, J. W., \& Kim, Y. G. (2001). Extending the TAM for a World-Wide-Web context. Information \& management, 38(4): 217-230. https://doi.org/10.1016/S03787206(00)00061-6

[41] Moreira, F., Ferreira, M. J., Santos, C, P., \& Durao, N. (2017). Evolution and use of mobile devices in higher education: A case study in Portuguese Higher Education Institutions between 2009/2010 and 2014/2015. Telematics and Informatics, 34(2017): 838-852. https://doi.org/10.1016/j.tele.2016.08.010

[42] Ong, C. S., \& Lai, J. Y. (2006). Gender differences in perceptions and relationships among dominants of e-learning acceptance. Computers in human behavior, 22(5): 816-829. https://doi.org/10.1016/j.chb.2004.03.006

[43] Park, S. Y., Nam, M. W., \& Cha, S. B. (2012). University students' behavioral intention to use mobile learning: Evaluating the technology acceptance model. British Journal of Educational Technology, 43(4): 592-605. https://doi.org/10.1111/j.1467-8535.2011.01229.x

[44] Phuangthong, D., \& Malisawan, S. (2005, August). A study of behavioral intention for 3G mobile Internet technology: Preliminary research on mobile learning. In Proceedings of the Second International Conference on eLearning for Knowledge-Based Society (pp. 4-7).

[45] Pituch, K. A., \& Lee, Y. K. (2006). The influence of system characteristics on e-learning use. Computers \& Education, 47(2): 222-244. https://doi.org/10.1 016/j.compedu.2004.10.007

[46] Rainie, L. (2012). Two-thirds of young adults and those with higher income are smartphone owers. Washington DC: Pew Research Center's Internet \& American Life Project. Retrieved August, 25, 1014 Retrieved from http://www.pewinternet.org/files/old-media/Files/Reports/2012/PIP_Smartphones_Sept12\%209\%2010\%2012.pdf(Accessed 11/ 05/2016)

[47] Rogers, K., Palmer, E \& Miller, J. (2017). Mobile earning in higher education: A comparative analysis of developed and developing country context. British Journal of Educational Technology, 1-16.

[48] Sánchez, R. A., \& Hueros, A. D. (2010). Motivational factors that influence the acceptance of Moodle using TAM. Computers in human behavior, 26(6): 1632-1640. https://doi.org/10.1016/j.chb.2010.06.011

[49] Sediyono, E., Kristinawati, W., \& Paseleng, M. C. (2018). Empowering Teachers in the Socialization of the Anti-Sexual Violence Behavior in Primary Schools. International Journal of Interactive Mobile Technologies, 12(8), 20-29. https://doi.org/10 $.3991 /$ ijim.v12i8.9641

[50] Sharples, M. (2000). The design of personal mobile technologies for lifelong learning. Computers \& Education, 34(3): 177-193. https://doi.org/10.1016/S0360-1315(99)00044-5

[51] Shih, J. L., Chu, H. C., \& Hwang, G. J. (2011). An investigation of attitudes of students and teachers about participating in a context-aware ubiquitous learning activity. British Journal of Educational Technology, 42(3): 373-394. https://doi.org/10.1111/j.14678535.2009.01020.x 
[52] Sommer, L. (2011). The theory of planned behaviour and the impact of past behaviour. The International Business \& Economics Research Journal, 10(1): 91-110 https://doi.org/10 19030/iber.v10i1.930

[53] Taylor, S., \& Todd, P. (1995). Assessing IT usage: The role of prior experience. MIS Quarterly, 19(4): 561-570 https://doi.org/10.2307/249633

[54] Tsai, M. T., Chen, K. S., \& Chien, J. L. (2012). The factors impact of knowledge sharing intentions: the theory of reasoned action perspective. Quality \& Quantity, 46(5): 1479-1491. https://doi.org/10.1007/s11135-011-9462-9

[55] Venkatesh, V., \& Davis, F. D. (2000). A theoretical extension of the technology acceptance model: Four longitudinal field studies. Management Science, 46(2): 186-204. https://doi.org/10.1287/mnsc.46.2.186.11926

[56] Wang, R., Wiesemes, R., \& Gibbons, C. (2012). Developing digital fluency through ubiquitous mobile devices: Findings from a small-scale study. Computers \& Education, 58(1): 570-578. https://doi.org/10.1016/j.compedu.2011.04.013

[57] Wu, P. H., Hwang, G. J., Tsai, C. C., Chen, Y. C., \& Huang, Y. M. (2011). A pilot study on conducting mobile learning activities for clinical nursing courses based on the repertory grid approach. Nurse Education Today, 31(8): e8-e15. https://doi.org/10 1016/j.nedt.2010.12.001

[58] Yunita, A., Nursechafia, N., Setiawan, E., Nugroho, H., \& Ramadhan, H. (2018). The Relationship between Mobile Phone Usage in Classroom and Academic Achievement in College Life. International Journal of Interactive Mobile Technologies, 12(8), 96-103. https://doi.org/10.3991/ijim.v12i8.9530

[59] Zidoun, Y., Talea, M., \& Dehbi, R. (2016). Students' Perception about Mobile Learning in Morocco: Survey Analysis. International Journal of Interactive Mobile Technologies, 10(4), 80-84. https://doi.org/10.3991/ijim.v10i4.5947

\section{Authors}

Dr Tinashe Chuchu Ph.D. is a Senior Lecturer in the Department of Marketing Management at the University of Pretoria. He is research area of focus is customer decision-making and marketing.

Dr Tinashe Ndoro Ph.D. is a Senior Lecturer in the Department of Marketing Management at the University of Pretoria. He is research area of focus is consumer behaviour.

Article submitted 2018-11-22. Resubmitted 2019-01-27. Final acceptance 2019-01-27. Final version published as submitted by the authors. 